\title{
Minerals Profile and Antioxidants Properties of Chickpea Leave of Desi and Kabuli Varieties at Different Stages of Maturity
}

\author{
Seema $^{1}$, Neelam Khetarpaul ${ }^{1}$ and Gurdev Chand $^{2^{*}}$ \\ ${ }^{1}$ Department of Foods and Nutrition, CCS Haryana Agricultural University, \\ Hisar-125 004 (Haryana), India \\ ${ }^{2}$ Division of Plant Physiology FBSc, SKUAST, Jammu-180009, India \\ *Corresponding author
}

\section{Keywords \\ Chickpea, Green leafy vegetables, Kabuli, Desi, Minerals, Antioxidants, Phenolic compounds \\ Article Info \\ Accepted: \\ 26 February 2018 \\ Available Online: \\ 10 March 2018}

\section{A B S T R A C T}

Chickpea (Cicer arietinum L.) the third most important food legume of the world and India is the leading producer and consumer of chickpea contributing to about $70 \%$ of the world chickpea production. Like other green leafy vegetables, chickpea leaves also contain good amount of minerals and powerful antioxidants. Phenolic agents are major class of antioxidants that are found in plant foods at very high concentration. Stages of maturity of leaves may effect on their mineral composition and antioxidants activity. So to determine the mineral composition of two desi (HC-1, C-235) and two Kabuli (HK-1, HK-2) varieties were studied for mineral profile and antioxidants at different stages (i.e. 30, 45, and 60 days after sowing) of maturity. Chickpea leaves were taken from department of Plant Breeding of CCS HAU Hisar. The young fully expanded leaves (fourth through seventh nods from the apex, up in triplicate) at 3 stages of maturity (30, 45 and 60 days) were collected. Then the leaves were washed in distilled water followed by drying at 65-70 degree centigrade for minimum of 48 hours, till the dry weight constant. All the total minerals like calcium, magnesium, potassium, phosphorus, iron, zinc, manganese, copper, and boron and nickel contents were maximum at 45 and 60 days after sowing in all the varieties. Antioxidants like phenolic compounds DPPH free radical scavenging activity and flavonoids in leaves of HK-1 were maximum at 45 and 60 days after sowing.

\section{Introduction}

Chickpea (Cicer arietinum L.) the third most important food legume of the world is commonly known as Chana and Garbanzo beans which is currently grown in about 10 million hectare of land worldwide with 95\% in the developing countries alone. Among the different pulses grown in the country, the respective share of production for chickpea is 40 per cent (Deshpande et al., 2011). Its average global productivity is $881 \mathrm{~kg}$ per hectare (Business Line, 2011).

India is the leading producer and consumer of Chickpea contributing to about $70 \%$ of the world chickpea production. Chickpea is consumed as a seed food, being a good source of energy (368 kcal) on protein $(21.0 \mathrm{~g})$, fat $(2.7 \mathrm{~g})$ and other essential human nutrients. Not only chickpea grain but its leaves are reported to be rich in various nutrients. So in 
the present scenario, it is important to use chickpea as a source of protein from grain as well as micronutrients from its leaves which have been underutilized and ignored in India for a long time. Chickpea included in the Indian vegetarian diets have a great role to prevent and control not only Protein Energy Malnutrition in India, but consumption of their leaves can combat micronutrient deficiency which is also very common. Multiple micronutrient deficiencies are more common than single deficiencies in developing countries like India and the cause for their high prevalence is low dietary intake by populations and poor bioavailability of micronutrients.

Green leafy vegetables are known to be rich sources of mineral contents and they also contain powerful antioxidants. Phenolic agents are a major class of antioxidants that are found in plants foods at very high concentration. Chickpea leaves are a very rich source of iron (23.8 $\mathrm{mg})$. It is, therefore, highly beneficial in the treatment of iron deficiency, anaemia. Like other green leafy vegetables, such as spinach, mustard leaves, mint, coriander leaves, chulai etc., chickpea leaves also contain good amount of some of the micronutrient minerals (Ibrikei et al., 2003) which are required to combat hidden hunger affecting $1 / 3^{\text {rd }}$ population of our country. There was a need to explore the nutrient composition with special reference to their mineral composition, bioavailability of minerals and anti-oxidant properties of such unconventional green leaves so as to prevent micronutrient deficiencies.

For chickpea leaves data on leaf mineral concentration are limited. For the effective use of leaves, we determined their mineral components and evaluated their antioxidant properties. Stage of maturity of plants affects the concentration of nutrients of leaves, thus it is very important to choose a suitable stage of harvesting (Yu et al., 2004).

\section{Materials and Methods}

The experiment was conducted at Department of Foods and Nutrition, CCS HAU, Hisar during 2012.

\section{Procurement of material}

Two desi (C-235, HC-I) and two kabuli (HKI, HK-2) chickpea varieties newly released by the Pulses Section, Department of Genetics and Plant Breeding of CCS HAU, Hisar were selected for the present study. The young fully expanded leaves (Fourth through seventh nodes from the apex, up in triplicate) at 3 stages of growth of chickpea i.e. 30, 45, 60 days after sowing were collected. After collection, the leaves were washed in distilled water and dried at $65-70^{\circ} \mathrm{C}$ for a minimum of $48 \mathrm{~h}$ or till the dried weight was constant (Plate 1a and 1b).

\section{Minerals analysis}

Total Minerals calcium $(\mathrm{Ca})$, magnesium $(\mathrm{Mg})$, potassium $(\mathrm{K})$, phosphorus $(\mathrm{P})$, iron $(\mathrm{Fe})$, zinc $(\mathrm{Zn})$, manganese $(\mathrm{Mn})$, copper $(\mathrm{Cu})$, Boron (B) and Nickel (Ni) were estimated by atomic absorption spectrophotometer by the method of Lindsey and Norwell, 1969.

\section{Anti-oxidant activity}

Anti-oxidant activity like total phenolic contents was measured by the method given by Singlton and Rass (1965). 2, 2'-Diphenyl1-picrylhydrazyl (DPPH) free radicals scavenging activity (RSA) was measured by the DPPH method of Hatno et al., (1988) and flavonoid content was measured by method describe by Jia et al., (1999).

\section{Statistical analysis}

Three replicate of each sample were used for statistical analysis using Duncan's new 
multiple range test (MRT) in SPSS version 16 taken from Computer Section, College of Basic Science, CCS HAU Hisar.

\section{Results and Discussion}

\section{Total minerals}

The data pertaining to total mineral present in the leaves at different intervals after sowing is presented in Tables 1 and 2. All the minerals like calcium, magnesium, potassium, phosphorus, iron, zinc, manganese, copper, and boron and nickel contents were found to be significantly $(\mathrm{p} \leq 0.05)$ higher at 45 days after sowing in leaves of both desi and kabuli chickpea varieties.

The leaves of C-235 desi variety had significantly $(\mathrm{p} \leq 0.05)$ higher iron content at 30,45 and 60 days after sowing when compared to that of HC-1 variety. The leaves of C-235 collected at 45 days after sowing had the highest amounts of calcium $(2.80 \mathrm{mg} / 100$ g), $\mathrm{Mg}(137 \mathrm{mg} / 100 \mathrm{~g})$ and $\mathrm{P}(387.67 \mathrm{mg} / 100$ g). The calcium content of leaves of HC-1 variety at 30 days after sowing was almost similar to that of C-235 varieties leaves collected at 60 days after sowing. Copper content of leaves of HC-1 collected at 30, 45 and 60 days after sowing were almost similar to those in leaves of C-235 variety at all days of growth.

The highest calcium content was found in the leaves of kabuli variety HK-1 $(2.68 \mathrm{~g} / 100 \mathrm{~g})$ followed by HK-2 (2.62 g/100 g) at 45 days after sowing. Magnesium content was significantly higher in the leaves of HK-1 $(139.67 \mathrm{mg} / 100 \mathrm{~g})$ and least was in HK-2 $(128.00 \mathrm{mg} / 100 \mathrm{~g})$ at 30 days after sowing. Similarly, potassium content was significantly higher in the leaves of HK-1 $(965.33 \mathrm{mg} / 100$ g) at 45 days after sowing than in the leaves of HK-2 at 30, 45 and 60 days after sowing. Phosphorus content was found maximum in the leaves of HK-1 and HK-2 (386.67 and $377.00 \mathrm{mg} / 100 \mathrm{~g}$ ) at 45 days after sowing than at 30 and 60 days after sowing. Iron content was again significantly higher in the leaves of kabuli variety HK-1 at 45 days after sowing $(360.00 \mathrm{mg} / 100 \mathrm{~g})$ than in the leaves of HK-2 at 30 and 60 days after sowing.

Total zinc content was found highest in the leaves of kabuli chickpea variety HK-1 (6.57 $\mathrm{mg} / 100 \mathrm{~g})$ and $\mathrm{HK}-2(6.37 \mathrm{mg} / 100 \mathrm{~g})$ at 45 days after sowing. Manganese content was found in the leaves of HK-2 $(1.42 \mathrm{mg} / 100 \mathrm{~g})$ and HK-1 $(1.39 \mathrm{mg} / 100 \mathrm{~g})$ at 45 days after sowing. Copper content was almost same in the leaves of HK-1 and HK-2 at 30, 45 and 60 days after sowing and ranged from 1.20 to $1.36 \mathrm{mg} / 100 \mathrm{~g}$. Highest boron content $(1.20$ $\mathrm{mg} / 100 \mathrm{~g}$ ) was found in the leaves of HK-1 and HK-2 at 60 days after sowing followed by HK-1 at 45 days after sowing $(1.07 \mathrm{mg} / 100 \mathrm{~g})$. Nickel content was found higher in the leaves of HK-1 and HK-2 at 45 and 60 days after sowing (Table 2).

\section{Antioxidant activity}

The phenolic content of leaves of HC-1 variety at 30, 45 and 60 days after sowing had $1.51,2.01$ and $2.01 \mathrm{GAE} / \mathrm{g}$, respectively. These values were significantly $(\mathrm{p} \leq 0.05)$ different from those noticed in leaves of C235 variety i.e. $1.48,1.98$ and $1.98 \mathrm{GAE} / \mathrm{g}$ after 30, 45 and 60 days after sowing. Phenolic compounds were significantly $(\mathrm{p} \leq$ 0.05 ) higher in leaves of both the desi varieties collected at 45 and 60 days after sowing.

Similar trend for phenolic compounds was observed in leaves of both the kabuli varieties. They had 1.50 to $2.02 \mathrm{GAE} / \mathrm{g}$ at varying intervals of growth of leaves (Tables 3 and 4). Diphenyl-I-Picrylhydrazyl (DPPH) and flavonoids activity also increased in leaves of both the desi and kabuli chickpea varieties as the growth period of leaves increased. 
Table.1 Total mineral content $(\mathrm{mg} / 100 \mathrm{~g})$ in leaves of desi chickpea varieties (On dry matter basis)

\begin{tabular}{|c|c|c|c|c|c|c|}
\hline \multirow[t]{3}{*}{ Total Minerals } & \multicolumn{3}{|c|}{ HC-1 variety } & \multicolumn{3}{|c|}{ C-235 variety } \\
\hline & \multicolumn{6}{|c|}{ Days after sowing (DAS) } \\
\hline & 30 & 45 & 60 & 30 & 45 & 60 \\
\hline $\begin{array}{l}\text { Calcium } \\
\text { (g/100 g) }\end{array}$ & $\begin{array}{c}2.63^{\mathrm{c}} \\
\pm 0.012\end{array}$ & $\begin{array}{c}2.72^{b} \\
\pm 0.009\end{array}$ & $\begin{aligned} & 2.5^{\mathrm{d}} \\
\pm & 0.0071\end{aligned}$ & $\begin{array}{c}2.71^{\mathrm{b}} \\
\pm 0.005\end{array}$ & $\begin{array}{c}2.80^{\mathrm{a}} \\
\pm 0.006\end{array}$ & $\begin{array}{c}2.62^{\mathrm{c}} \\
\pm 0.011\end{array}$ \\
\hline Magnesium & $\begin{array}{c}126.33^{\mathrm{e}} \\
\pm 0.88\end{array}$ & $\begin{array}{c}133.00^{b} \\
\pm 0.58\end{array}$ & $\begin{array}{c}131.00^{\mathrm{c}} \\
\pm 0.58\end{array}$ & $\begin{array}{c}128.67^{\mathrm{d}} \\
\pm 0.33\end{array}$ & $\begin{array}{c}137.00^{\mathrm{a}} \\
\pm 0.58\end{array}$ & $\begin{array}{c}134.00^{b} \\
\pm 0.58\end{array}$ \\
\hline Potassium & $\begin{array}{c}947.00^{\mathrm{b}} \\
\pm 0.58\end{array}$ & $\begin{array}{c}951.67^{\mathrm{a}} \\
\pm 1.20\end{array}$ & $\begin{array}{c}942.33^{c} \\
\pm 0.88\end{array}$ & $\begin{array}{c}945.00^{\mathrm{bc}} \\
\pm 0.58\end{array}$ & $\begin{array}{c}953.33^{\mathrm{a}} \pm \\
1.45\end{array}$ & $\begin{array}{c}935.33^{d} \\
\pm 1.76\end{array}$ \\
\hline Phosphorus & $\begin{array}{c}355.67^{\mathrm{de}} \\
\pm 3.18\end{array}$ & $\begin{array}{c}372.00^{b} \\
\pm 3.06\end{array}$ & $\begin{array}{c}348.00^{\mathrm{e}} \\
\pm 2.08\end{array}$ & $\begin{array}{c}367.33^{b c} \\
\pm 3.93\end{array}$ & $\begin{array}{c}387.67^{\mathrm{a}} \pm \\
2.33\end{array}$ & $\begin{array}{c}359.33^{\mathrm{cd}} \\
\pm 4.33\end{array}$ \\
\hline Iron & $\begin{array}{c}507.67^{b c} \\
\pm 2.33\end{array}$ & $\begin{array}{c}518.33^{\mathrm{b}} \\
\pm 2.03\end{array}$ & $\begin{array}{c}505.33^{c} \\
\pm 2.03\end{array}$ & $\begin{array}{c}545.33^{\mathrm{a}} \\
\pm 4.10\end{array}$ & $\begin{array}{c}555.33^{\mathrm{a}} \pm \\
5.54\end{array}$ & $\begin{array}{c}546.33^{\mathrm{a}} \\
\pm 4.26\end{array}$ \\
\hline Zinc & $\begin{array}{l}6.00^{\mathrm{d}} \\
\pm 0.06\end{array}$ & $\begin{array}{l}6.40^{\mathrm{ab}} \\
\pm 0.06\end{array}$ & $\begin{array}{l}6.10^{\mathrm{cd}} \\
\pm 0.06\end{array}$ & $\begin{array}{l}6.10^{\mathrm{ed}} \\
\pm 0.06\end{array}$ & $\begin{array}{l}6.53^{\mathrm{a}} \\
\pm 0.07\end{array}$ & $\begin{array}{l}6.27^{\mathrm{bc}} \\
\pm 0.07\end{array}$ \\
\hline Manganese & $\begin{array}{l}1.20^{\mathrm{ab}} \\
\pm 0.06\end{array}$ & $\begin{array}{l}1.30^{\mathrm{a}} \\
\pm 0.06\end{array}$ & $\begin{array}{l}1.10^{\mathrm{b}} \\
\pm 0.06\end{array}$ & $\begin{array}{l}1.22^{\mathrm{ab}} \\
\pm 0.06\end{array}$ & $\begin{array}{l}1.32^{\mathrm{a}} \\
\pm 0.06\end{array}$ & $\begin{array}{c}1.15^{\mathrm{ab}} \\
\pm .05\end{array}$ \\
\hline Copper & $\begin{array}{l}1.10^{\mathrm{a}} \\
\pm 0.06\end{array}$ & $\begin{array}{l}1.20^{\mathrm{a}} \\
\pm 0.06\end{array}$ & $\begin{array}{l}1.20^{\mathrm{a}} \\
\pm 0.06\end{array}$ & $\begin{array}{l}1.16^{\mathrm{a}} \\
\pm 0.04\end{array}$ & $\begin{array}{l}1.24^{\mathrm{a}} \\
\pm 0.05\end{array}$ & $\begin{array}{l}1.28^{\mathrm{a}} \\
\pm 0.06\end{array}$ \\
\hline Boron & $\begin{array}{l}0.70^{\mathrm{c}} \\
\pm 0.06\end{array}$ & $\begin{array}{l}0.90^{b c} \\
\pm 0.06\end{array}$ & $\begin{array}{l}1.10^{\mathrm{ab}} \\
\pm 0.06\end{array}$ & $\begin{array}{l}0.70^{\mathrm{c}} \\
\pm 0.06\end{array}$ & $\begin{array}{l}0.90^{\mathrm{bc}} \\
\pm 0.01\end{array}$ & $\begin{array}{r}1.17^{\mathrm{a}} \\
\pm 0.09\end{array}$ \\
\hline Nickel & $\begin{array}{l}0.97^{\mathrm{b}} \\
\pm 0.01\end{array}$ & $\begin{array}{l}1.03^{\mathrm{a}} \\
\pm 0.02\end{array}$ & $\begin{array}{l}1.03^{\mathrm{a}} \\
\pm 0.02\end{array}$ & $\begin{array}{l}0.98^{b} \\
\pm 0.07\end{array}$ & $\begin{array}{l}1.05^{\mathrm{a}} \\
\pm 0.02\end{array}$ & $\begin{array}{l}1.04^{\mathrm{a}} \\
\pm 0.07\end{array}$ \\
\hline
\end{tabular}

Values are mean \pm SE of three independent determinations.

The mean values in same row with different superscripts differ significantly $(\mathrm{p} \leq 0.05)$.

Table.2 Total mineral content $(\mathrm{mg} / 100 \mathrm{~g})$ in leaves of kabuli chickpea varieties (On dry matter basis)

\begin{tabular}{|c|c|c|c|c|c|c|}
\hline \multirow[t]{3}{*}{ Total minerals } & \multicolumn{3}{|c|}{ HK-1 variety } & \multicolumn{3}{|c|}{ HK-2 variety } \\
\hline & \multicolumn{6}{|c|}{ Days after sowing (DAS) } \\
\hline & 30 & 45 & 60 & 30 & 45 & 60 \\
\hline $\begin{array}{l}\text { Calcium } \\
(\mathrm{g} / 100 \mathrm{~g})\end{array}$ & $\begin{array}{c}2.55^{\mathrm{c}} \\
\pm 0.019\end{array}$ & $2.68^{\mathrm{a}} \pm 0.011$ & $2.45^{\mathrm{e}} \pm 0.008$ & $\begin{array}{c}2.51^{\mathrm{d}} \pm \\
0.003\end{array}$ & $2.62^{b} \pm 0.016$ & $2.42^{\mathrm{e}} \pm 0.004$ \\
\hline Magnesium & $\begin{array}{c}132.00^{\mathrm{c}} \\
\pm 1.15\end{array}$ & $\begin{array}{c}139.67^{\mathrm{a}} \pm \\
1.20\end{array}$ & $135.67^{b} \pm 1.45$ & $\begin{array}{c}128.00^{\mathrm{d}} \\
\pm .58\end{array}$ & $132.00^{\mathrm{c}} \pm 1.16$ & $129.33^{\mathrm{cd}} \pm 0.88$ \\
\hline Potassium & $\begin{array}{c}956.33^{\mathrm{b}} \\
\pm .88\end{array}$ & $\begin{array}{c}965.33^{\mathrm{a}} \pm \\
2.03\end{array}$ & $947.00^{c} \pm 1.53$ & $\begin{array}{c}943.67^{c} \pm \\
0.88\end{array}$ & $946.33^{c} \pm 1.20$ & $937.00^{d} \pm 1.53$ \\
\hline Phosphorus & $\begin{array}{c}353.67^{\mathrm{b}} \\
\pm 3.84\end{array}$ & $\begin{array}{c}386.67^{\mathrm{a}} \pm \\
2.91\end{array}$ & $355.33^{b} \pm 5.21$ & $\begin{array}{c}349.00^{\mathrm{b}} \pm \\
3.61\end{array}$ & $377.00^{\mathrm{a}} \pm 3.22$ & $347.00^{b} \pm 4.58$ \\
\hline Iron & $\begin{array}{c}520.67^{\text {bc }} \\
\pm 8.82\end{array}$ & $\begin{array}{c}560.00^{\mathrm{a}} \pm \\
8.72\end{array}$ & $524.00^{b} \pm 7.57$ & $\begin{array}{c}494.33^{\mathrm{d}} \pm \\
3.53\end{array}$ & $515.33^{b c} \pm 3.53$ & $502.33^{\mathrm{cd}} \pm 2.40$ \\
\hline Zinc & $\begin{array}{c}6.27^{b} \\
\pm 0.90\end{array}$ & $6.57^{\mathrm{a}} \pm .15$ & $6.10^{b c} \pm 0.60$ & $5.90^{\mathrm{c}} \pm 0.06$ & $6.37^{\mathrm{ab}} \pm 0.98$ & $\begin{array}{l}6.10^{\mathrm{bc}} \\
\pm 0.06\end{array}$ \\
\hline Manganese & $\begin{array}{l}1.29^{\mathrm{b}} \\
\pm 0.01\end{array}$ & $1.39^{\mathrm{a}} \pm 0.01$ & $1.19^{\mathrm{d}} \pm 0.01$ & $1.32^{\mathrm{b}} \pm 0.01$ & $1.42^{\mathrm{a}} \pm 0.01$ & $\begin{array}{l}1.23^{\mathrm{c}} \\
\pm 0.02\end{array}$ \\
\hline Copper & $\begin{array}{l}1.22^{\mathrm{a}} \\
\pm 0.06\end{array}$ & $1.36^{\mathrm{a}} \pm 0.06$ & $1.34^{\mathrm{a}} \pm 0.08$ & $1.20^{\mathrm{a}} \pm 0.06$ & $1.30^{\mathrm{a}} \pm 0.06$ & $\begin{array}{r}1.30^{\mathrm{a}} \\
\pm 0.06\end{array}$ \\
\hline Boron & $\begin{array}{l}0.87^{\mathrm{c}} \\
\pm 0.03\end{array}$ & $1.07^{b} \pm 0.03$ & $1.20^{\mathrm{a}} \pm 0.00$ & $0.83^{c} \pm 0.03$ & $1.03^{b} \pm 0.04$ & $\begin{array}{r}1.20^{\mathrm{a}} \\
\pm 0.06\end{array}$ \\
\hline Nickel & $\begin{array}{l}0.97^{\mathrm{b}} \\
\pm 0.00\end{array}$ & $1.03^{\mathrm{a}} \pm 0.02$ & $1.03^{\mathrm{a}} \pm 0.02$ & $0.97^{b} \pm 0.01$ & $1.04^{\mathrm{a}} \pm 0.02$ & $\begin{array}{l}1.05^{\mathrm{a}} \\
\pm 0.02\end{array}$ \\
\hline
\end{tabular}

Values are mean $\pm \mathrm{SE}$ of three independent determinations.

The mean values in same row with different superscripts differ significantly $(p \leq 0.05)$. 
Table.3 Antioxidant activity in leaves of desi chickpea varieties (on dry matter basis)

\begin{tabular}{|c|c|c|c|c|c|c|}
\hline \multirow[t]{3}{*}{ Anti-oxidants } & \multicolumn{3}{|c|}{ HC-1 variety } & \multicolumn{3}{|c|}{ C-235 variety } \\
\hline & \multicolumn{6}{|c|}{ Days after sowing (DAS) } \\
\hline & 30 & 45 & 60 & 30 & 45 & 60 \\
\hline $\begin{array}{l}\text { Phenolic compounds } \\
\text { (mg GAE/g) }\end{array}$ & $\begin{array}{l}1.51^{\mathrm{c}} \\
\pm 0.46\end{array}$ & $\begin{array}{l}2.01^{\mathrm{a}} \\
\pm 1.16\end{array}$ & $\begin{array}{r}2.01^{\mathrm{a}} \\
\pm 0.98\end{array}$ & $\begin{array}{r}1.48^{\mathrm{d}} \\
\pm 0.48\end{array}$ & $\begin{array}{r}1.98^{b} \\
\pm 0.69\end{array}$ & $\begin{array}{r}1.98^{b} \\
\pm 0.80\end{array}$ \\
\hline DPPH RSA $(\mu \mathrm{g})$ & $\begin{array}{r}7.87^{c} \\
\pm 0.06\end{array}$ & $\begin{array}{r}8.01^{\mathrm{a}} \\
\pm 0.06\end{array}$ & $\begin{array}{l}8.01^{\mathrm{a}} \\
\pm 0.06\end{array}$ & $\begin{array}{r}7.86^{c} \\
\pm 0.06\end{array}$ & $\begin{array}{l}8.00^{\mathrm{ab}} \\
\pm 0.06\end{array}$ & $\begin{array}{r}7.99^{b} \\
\pm 0.06\end{array}$ \\
\hline Flavonoids (mg/g) & $\begin{array}{r}1.80^{\mathrm{a}} \\
\pm 0.06\end{array}$ & $\begin{array}{r}1.90^{\mathrm{a}} \\
\pm 0.06\end{array}$ & $\begin{array}{l}1.90^{\mathrm{a}} \\
\pm 0.06\end{array}$ & $\begin{array}{r}1.78^{\mathrm{a}} \\
\pm 0.01\end{array}$ & $\begin{array}{r}1.88^{\mathrm{a}} \\
\pm 0.01\end{array}$ & $\begin{array}{r}1.87^{\mathrm{a}} \\
\pm 0.01\end{array}$ \\
\hline
\end{tabular}

Values are mean $\pm \mathrm{SE}$ of three independent determination.

The mean values in same row with different superscripts differ significantly $(\mathrm{p} \leq 0.05)$.

Table.4 Antioxidant activity in leaves of kabuli chickpea varieties (on dry matter basis)

\begin{tabular}{|c|c|c|c|c|c|c|}
\hline \multirow[t]{3}{*}{ Anti-oxidants } & \multicolumn{3}{|c|}{ HK-1 variety } & \multicolumn{3}{|c|}{ HK-2 variety } \\
\hline & \multicolumn{6}{|c|}{ Days after sowing (DAS) } \\
\hline & 30 & 45 & 60 & 30 & 45 & 60 \\
\hline $\begin{array}{l}\text { Phenolic compounds } \\
\text { (mg GAE/g) }\end{array}$ & $\begin{array}{l}1.50^{\mathrm{c}} \\
\pm 0.24\end{array}$ & $\begin{array}{l}2.02^{\mathrm{a}} \\
\pm 0.52\end{array}$ & $\begin{array}{r}2.01^{\mathrm{a}} \\
\pm 0.55\end{array}$ & $\begin{array}{r}1.52^{b} \\
\pm 0.17\end{array}$ & $\begin{array}{l}2.01^{\mathrm{a}} \\
\pm 0.76\end{array}$ & $\begin{array}{l}2.01^{\mathrm{a}} \\
\pm 0.61\end{array}$ \\
\hline DPPH RSA $(\mu \mathrm{g})$ & $\begin{array}{l}7.90^{c} \\
\pm 0.06\end{array}$ & $\begin{array}{l}8.00^{b} \\
\pm 0.09\end{array}$ & $\begin{array}{l}8.01^{b} \\
\pm 0.06\end{array}$ & $\begin{array}{r}7.92^{c} \\
\pm 0.12\end{array}$ & $\begin{array}{l}8.02^{a b} \\
\pm 0.06\end{array}$ & $\begin{array}{l}8.04^{\mathrm{a}} \\
\pm 0.06\end{array}$ \\
\hline Flavonoids (mg/g) & $\begin{array}{l}1.86^{\mathrm{d}} \\
\pm 0.01\end{array}$ & $\begin{array}{r}1.95^{b} \\
\pm 0.01\end{array}$ & $\begin{array}{l}1.93^{c} \\
\pm 0.01\end{array}$ & $\begin{array}{r}1.87^{\mathrm{d}} \\
\pm 0.01\end{array}$ & $\begin{array}{l}1.97^{\mathrm{a}} \\
\pm 0.01\end{array}$ & $\begin{array}{l}1.98^{\mathrm{a}} \\
\pm 0.01\end{array}$ \\
\hline
\end{tabular}

Values are mean \pm SE of three independent determinations.

The mean values in same row with different superscripts differ significantly $(\mathrm{p} \leq 0.05)$.

DDPH: Diphenyl-I-Picrylhydrazyl.

Total minerals like boron, calcium, copper, iron, magnesium, nickel and zinc in the chickpea leaves were found to increase with the crop growth and found to maximum at maturity. Total boron content (mg / $100 \mathrm{~g}$ ) was found maximum in the leaves of HK-1 (1.20) and HK-2 (1.20), C-235 (1.17) and HC-1 (1.10) at 60 days after sowing. Copper content was found maximum in variety HK-1 (1.36 and $1.34 \mathrm{mg} / 100 \mathrm{~g}$ ) at 45 and 60 days after sowing.

Highest potassium content $(965.33 \mathrm{mg} / 100 \mathrm{~g})$ in leaves of chickpea variety HK-1 was observed at 45 days after sowing. Singh and Saxena (1972) reported that different stages of maturity did not affect the potassium contents of the leaves. Giri et al., (1984) reported that potassium decreased with the age of the Chekurmeni plant. Sodium and potassium are important interacellular and extracellular cations, respectively.

The importance of $\mathrm{Na} / \mathrm{K}$ ratio in the body in the body in controlling high blood pressure cannot be over emphasized (Yusuf et al., 2007). Phosphorus content was found maximum in the middle stage of the growth of chickpea and it reduced with growth and lowest at maturity. Copper content was found maximum in variety HK-1 (1.36 and $1.34 \mathrm{mg}$ / $100 \mathrm{~g}$ ) at 45 and 60 days after sowing. 
The main characteristic of an antioxidant is its ability to trap free radicals. Highly reactive free radicals and oxygen species are present in biological systems from a wide variety of sources. These free radicals may oxidize nucleic acids, proteins, lipids or DNA and can initiate degenerative disease. Antioxidant compounds like phenolic acids, polyphenols and flavonoids scavenge free radicals such as peroxide, hydroperoxide or lipid peroxyl and thus, inhibit the oxidative mechanisms that lead to degenerative diseases.

DPPH per cent inhibition content was significantly $(\mathrm{p} \leq 0.05)$ higher at 45 and 60 days after sowing as compared the DPPH content of leaves taken at 30 days after sowing. The flavonoid contents are also increased with the age of the chickpea crop. The highest flavonoid content was obtained in the leaves of HK-2 at 45 and 60 days after sowing (1.97 and $1.98 \mathrm{mg} / \mathrm{g}$ ) and lowest was estimated in the leaves of C-235 variety at 30 days after sowing $(1.78 \mathrm{mg} / \mathrm{g})$. The phenolic content in the leaves of chickpea increased with the age of the chickpea. It was found maximum in the leaves obtained from 45 and 60 days chickpea crop. Singh et al., (2012) reported phenolic compound $(0.2 \%)$ in the leaves of bael. Khattak (2011) reported that the phenolic content of flower buds of Kachnar (Bauhinia variegate Linn.) and phenolic compounds leaves of purslane (Portulaca oleracea Linn.) were statistically same ( $\mathrm{p}>0.05)$ (111.7). Increased dietary ingestion of natural phenolic compounds may reduce coronary heart diseases and have therefore a full range of perspective uses in healthcare. Earlier the phenolic components have shown an affinity to quench reactive oxygen species by flavonoids of Gingko biloba (Mahady, 2002).

The present study has provided some comparative biochemical information on the mineral composition and anti-oxidant properties of three different stages of maturity of two kabuli and two desi chickpea leaves. Highest total minerals like phosphorus, calcium and nickel were found in the leaves of desi chickpea variety C-235 i.e., 387.67, 2.8 and $1.05 \mathrm{mg} / 100 \mathrm{~g}$, respectively, at 45 days after sowing. But potassium, iron, magnesium, zinc, copper and boron contents were found maximum in the leaves of kabuli chickpea variety HK-1, i.e., 965.33, 560, $139.67,6.57$ and $1.36 \mathrm{mg} / 100 \mathrm{~g}$, respectively, at 45 days after sowing. On the other hand boron was highest $(1.20 \mathrm{mg} / 100 \mathrm{~g})$ at 60 DAS. The total manganese content was found maximum in the leaves of HK-2 (1.42 $\mathrm{mg} / 100 \mathrm{~g}$ ) at 60 days after sowing while antioxidant activity as governed by phenolic compounds in leaves of kabuli chickpea variety HK-1 (2.02 mg GAE / g, 45 DAS), DPPH content in HK-2 (8.04\%; 60 DAS) and flavonoid content in HK-2 (1.98 mg / g; 60 DAS) were found to be the highest.

\section{References}

Business Line (2011) Chickpea cultivation holds promise. Business Daily form Hindu Group of Publications, Jan. 03.

Deshpande, H. W., Sompure, S. S., Ghatge, P. U., Machewadand, G. M. and Gadhe, K. S. (2011) Studies on development of instant whole legumes (Bengal gram). Beverage Food World, 56, 23-26.

Giri, J.; Bhuvaneswari, W. and Rajeshwari, D. (1984) Changes in the Nutritive value of Chekurmenis at different stages of growth. Indian J. Nutr. Diet., 21, 419-423.

Hatano, T., H. Kagawa, T. Yasuhara and T. Okuda. 1988. Two new flavonoids and other constituents in licorice root; their relative astringency and radical scavenging effects. Chem. Pharmaceut. Bull., 36, 2090-2097.

Ibrikei, H., Knewtson, JB. S. and Grusak, A.M. (2003) Chickpea leaves as a 
vegetable green for humans: evaluation of mineral composition. J Sci Food Agric., 83, 945-950.

Jia, Z., Tang, M. and Wu, J. (1999) The determination of flavonoid contents in mulberry and their scavenging effects on superoxide radicals. Food Chem., 64, $555-559$.

Khattak, K. F. (2011) Nutrient composition, phenolic content and free radical scavenging activity of some uncommon vegetables of Pakistan. Pak. J. Pharm. Sci., 24(3), 277 - 283.

Lindsey, W. L. and Norewell, M. A. (1969) A new DPTA-TEA soil test for zinc and iron. Agron. Abst., 61, 84.

Mahady, G. B. (2002) Ginkgo biloba for the prevention and treatment of cardiovascular disease: A review of the literature. J. Cardiovasc. Nurs., 16, 2132.

Singh, P. P and Saxena, S. N. (1972) Effect of maturity on the oxalate and cation contents of six leafy vegetables. Indian J. Nutr. Diet., 9, 269-276.
Singh, U., Kochar, A. and Boora, R. (2012) Proximate composition, available carbohydrates, dietary fibres and antinutritional factors in bael (Aegle maemelos L.) leaf, pulp and seed powder. International Journal of Scientific and Research Publications, 2(4), 1-4.

Singleton, V. L. and Rass, J. A. (1965) Calorimetry of total phenols with phosphomolybdic-phasphotungstic acid reagents. Am. J. Enology Viticulture, 16, 144-158.

$\mathrm{Yu}, \mathrm{P}$., Christensen, D. A. and McKinnon, J. J. (2004) In situ rumen degradation kinetics of timothy and alfalfa as affected by cultivar and stage of maturity. Can. J. Anim. Sci., 84, 255263.

Yusuf, A. A., Mofia, B. M. and Ahmed, A. B. (2007) Proximate and Minerals Composition of Tramarindus indica Linn 1753 seeds. Science World Journal, 2, 1-4.

\section{How to cite this article:}

Seema, Neelam Khetarpaul and Gurdev Chand. 2018. Minerals Profile and Antioxidants Properties of Chickpea Leave of Desi and Kabuli Varieties at Different Stages of Maturity. Int.J.Curr.Microbiol.App.Sci. 7(03): 3171-3177. doi: https://doi.org/10.20546/ijcmas.2018.703.366 